The Journal of Poultry Science, 43 : 54-59, 2006

\title{
The Effect of Proctodeal Gland Foam, Diluent and Dimethylacetamide Addition on Morphology and Fertilising Ability of Japanese Quail (Coturnix japonica) Spermatozoa
}

\author{
Bronisława Chełmońska, Ewa Lukaszewicz, Artur Kowalczyk and Anna Jerysz \\ Department of Poultry Breeding, Agricultural University of Wrocław, \\ Chełmońskiego 38C, 51-630 Wrocław, Poland
}

\begin{abstract}
The effect of proctodeal gland foam addition to fresh net or diluted semen supplemented with (DMA) dimethylacetamide, on morphology and fertilising potency of quail spermatozoa was evaluated.

Every stage of quail semen preparation caused an increase in sperm deformations. The addition of foam, diluent and DMA decreased the number of morphologically intact spermatozoa by 28.3 percent points, in relation to the fresh semen.

Foam addition to the fresh semen allowed to obtain $91.4 \%$ fertility, which was similar to results obtained during natural mating $(93.0 \%)$, but in diluted and DMA supplemented semen, equilibrated for 5 minutes at $4{ }^{\circ} \mathrm{C}$, the foam had a detrimental effect on fertilising ability of spermatozoa.
\end{abstract}

Key words : cryoprotectant, fertility, foam, spermatozoa morphology, quail

\section{Introduction}

Sexually mature quail males have the unique proctodeal gland, located just behind the cloacal opening. The gland, responsible for the secretion of thick foam, is evidently sexually dimorphic (large in sexually active males and rudimentary in females) and dependent on testosterone stimulation (Adkins-Regan, 1999). Males with well developed proctodeal gland are characterised by high fertilising potency and produce dense, white foam (Mohan et al., 2000). During natural mating male always introduces semen together with the foam to female reproductive tract, but never semen alone (Adkins, 1974 ; Cheng et al., 1989 a ; Seiwert and Adkins-Regan, 1998). The foam may serve as a medium for semen transportation, as well as in providing the spermatozoa activity within the female oviduct (Cheng et al., 1989 a ; Fujihara, 1992).

Studies on cryopreservation of bird semen have been carried out for more than 60 years. The different semen extenders, cryoprotective agents, temperature and time of equilibration, temperature decrease (during freezing) and increase rates (during thawing) were tested (Blanco et al., 2000 ; Lukaszewicz, 2001 ; 2002 ; Tselutin et al., 1999). The spermatozoa morphology, viability and motility, as well as the insemination dose, frequency of insemination and fertilising ability were also studied (Donoghue and Wishart, 2000).

In the freezing-thawing process cellular membranes, including those of spermatozoa, have to withstand an osmotic and cryoinjury stress, there-

Received : March 1, 2005, Accepted : March 25, 2005

Corresponding author : Ewa Lukaszewicz, Agricultural University of Wrocław Department of Poultry Breeding Chełmońskiego 38c, 51-630 Wrocław, Poland

Phone : +48 713205774 Fax : +48 713205776 E-mail : ewakoch@o2.pl ; ewa@gen.ar.wroc.pl

This work was supported by Grant No 6P0 6D 04221 
fore the addition of cryoprotective agent is necessary to avoid, or at least to minimise, the harmful effect of water crystallisation during freezing or re-crystallisation, during thawing. For freezing poultry semen, glycerol, (DMSO) dimethylsulphoxide, ethylene glycol and DMA have been successfully used. Tselutin et al. (1999) when comparing the effect of glycerol, DMSO and DMA on viability and integrity of fowl spermatozoa measured with eosin-nigrosin smears, found glycerol to be the least deleterious and DMSO - to be the most toxic. In our previous experiments on cryoprotectant effect on quail spermatozoa morphology (unpublished data), DMA was stated the most effective, when compared to ethylene glycol, DMF (dimethylformamide) and DMSO.

The results of experiments carried out in order to determine the significance and function of foam produced in quail proctodeal gland, in relation to fertilising ability of semen stored in vitro were described by Fujihara et al. (1989) and Fujihara and Koga (1991). However, in the available literature any paper relating to quail semen preservation in liquid nitrogen was found.

The aim of the present studies was to determine the influence of different factors that may affect further success of quail semen cryopreservation. The effect of Lake's extender, DMA and proctodeal gland foam addition on morphology and fertilising potency of Japanese quail (Coturnix japonica) spermatozoa was studied.

\section{Materials and Methods}

Seventy five males kept individually in cages ( 32 $\times 44 \times 24 \mathrm{~cm})$, and 52 females kept in 5-tier battery cage $(1.0 \times 0.55 \times 1.75 \mathrm{~m}$.), at room temperature $\left(20-22^{\circ} \mathrm{C}\right)$ were used in the experiment. Birds at the age of four months were randomly divided into four groups. Experiment schedule is given in Table 1. Feeding and management system was followed in accordance with recommendations for reproductive quail.

The semen was collected with male stimulation by female method (Chełmońska et al., 2005). Five sexually matured females characterised by quiet temperament, and displaying the tolerance reflex that would enable males to ascent on them quickly were used. Before semen collection the foam was removed from proctodeal gland by delicate squeezing the lateral wall of cloaca.

Freshly collected semen was mixed $(1: 1)$ with the foam (group II and IV) or diluted at $20^{\circ} \mathrm{C}$ with a half volume of Lake's extender (Lake, 1960), then cooled to $4^{\circ} \mathrm{C}$ and kept for 20 minutes before the supplementation with another half of extender containing particular concentration of DMA $(6 \%$ in final concentration, and previously cooled to $4^{\circ} \mathrm{C}$ (group III and IV) (Table 1). Semen obtained from group I and II was used for insemination immediately after collection and supplementation with foam (semen temperature was $20^{\circ} \mathrm{C}$ ). Semen from groups III and IV was used for insemination after the subsequent 5 minutes of equilibration at $4^{\circ} \mathrm{C}$ (temperature of inseminated semen was $4^{\circ} \mathrm{C}$ ). For semen extending only clean, white and dense foam of good quality was used.

The fecundity of control and experimental groups was compared with the results obtained in naturally mated group.

Semen collection and female insemination were performed 11 times, 3 times a week (Table 1).

Spermatozoa morphology was assessed in pooled semen on the basis of histological smears, vitalstained by nigrosin-eosin complex. Smears were prepared after every step of treatment (i.e. in the fresh semen, semen supplemented with foam,

Table 1. Schedule of the experiment

\begin{tabular}{cclccc}
\hline \hline $\begin{array}{c}\text { Males } \\
\text { group }\end{array}$ & $\begin{array}{c}\text { Males } \\
(\text { No) }\end{array}$ & \multicolumn{1}{c}{ Semen sample } & $\begin{array}{c}\text { Semen dose } \\
(\mu l)\end{array}$ & $\begin{array}{c}\text { Females' } \\
\text { group }\end{array}$ & $\begin{array}{c}\text { Females } \\
\left(\mathrm{N}^{\circ}\right)\end{array}$ \\
\hline I & 12 & Fresh undiluted - control group & 10 & $\mathrm{~A}$ & 10 \\
II & 20 & $10 \mu l$ semen $+10 \mu l$ foam & 20 & $\mathrm{~B}$ & 10 \\
III & 20 & $10 \mu l$ semen $+40 \mu l$ extender $+6 \%$ DMA & 50 & $\mathrm{C}$ & 10 \\
IV & 20 & $10 \mu l$ semen $+10 \mu l$ foam $+30 \mu l$ extender $+6 \%$ DMA & 50 & $\mathrm{D}$ & 10 \\
& 3 & Naturally mated group & - & $\mathrm{E}$ & 12 \\
\hline
\end{tabular}


diluted with Lake's extender, after DMA addition and in samples remaining after insemination), separately for each group. In each smear, 300 spermatozoa, observed under oil immersion objective ( $\times 1250$ magnification), were morphologically categorised into following forms : live normal (typical spindle-shaped head and well-marked acrosome) ; bulb-head (macrocephalic head); bent-neck (cells broken at the head-midpiece junction); acrosome deformed (rugged or lack of acrosome) ; spermatids (immature cells), other deformities (not considered in previous categories), and dead spermatozoa (pinkish, completely or partly stained by eosin).

The effect of each stage of semen treatment on number of live normal spermatozoa was expressed as the relative changes, i.e. percent of spermatozoa which remained after particular stage, in relation to the fresh semen $(100 \%)$.

The number of live normal cells introduced to female reproductive tract with the inseminated semen was calculated in the following way : sperm concentration in the fresh semen $(\mathrm{m} l) \times$ amount of live normal cells $(\%) \times$ volume of insemination dose $(\mathrm{m} l)$.

Eggs were collected 2-3 times/day and set daily into Masalles incubator. Fertility was assessed macroscopically by observation on blastoderm development in eggs incubated for 24 hours.

The data obtained were analysed by ANOVA and Duncan multiple range tests (SAS system, General Linear Models Procedure).

\section{Results and Discussion}

The volume of ejaculates collected from Japanese quails is the smallest among all poultry species. The volume of pooled ejaculates collected during the present studies varied from 150 to $200 \mu l$ ( $200 \mu l$ on average) in the control group (12 males) and from 300 to $400 \mu l$ ( $360 \mu l$ on average) in the experimental groups (20 males). Therefore, the average volume of single ejaculate varied form 12.5 to $20 \mu \mathrm{l}$. No differences between the experimental groups were stated. Ejaculates of similar volumes $(10 \mu l$ from one male) were collected by Wentworth and Mellen (1963), Baumgartner (1990) (10-20 $\mu \mathrm{l})$ and Tarasewicz et al. (1997) (5-20 $\mathrm{ll})$.

Sperm concentration in pooled ejaculates varied from 2.06 to $3.0 \times 10^{9} \mathrm{~m} l^{-1}$. There were no signifi- cant differences in spermatozoa concentration between the experimental groups, but the parameter was significantly lower $(P \leq 0.05)$ in comparison with the control group, in which the concentration was the highest $\left(2.6 \times 10^{9} \mathrm{~m} l^{-1}\right)$. Sperm concentration in collected ejaculates was higher than that obtained by Fujihara and Koga (1991) $\left(0.043 \times 10^{9}\right.$ $\left.\mathrm{m} l^{-1}\right)$, Baumgartner (1990) $\left(0.052-0.059 \times 10^{9}\right.$ $\left.\mathrm{m} l^{-1}\right)$, Bunaciu et al. (1994) $\left(0.22-0.33 \times 10^{9} \mathrm{~m} l^{-1}\right)$, Buxton and Orcutt (1975) $\left(0.469 \times 10^{9} \mathrm{~m} l^{-1}\right)$ or Tarasewicz et al. (1997) $\left(0.12-0.312 \times 10^{9} \mathrm{~m} l^{-1}\right)$.

Similarly, there were no differences in the amount of live, morphologically normal spermatozoa in semen collected from the experimental groups (group II-IV). The character varied from 43.3 to $64.7 \%$, and was significantly $(P \leq 0.01)$ lower in relation to the control group (I), in which the number of normal spermatozoa was the highest (varying from 54.7 to $75.0 \%$ ). The data obtained in the course of experiment are given in Tables 2 and 3 .

Foam addition to semen of group II and IV caused a decrease in the number of normal cells by 6.0 and 7.5 percent points, respectively (there were 88.8 and $85.6 \%$ of normal cells in relation to the fresh semen). A similar trend was stated for group III, the semen of which was diluted with Lake's extender $(86.3 \%$ of cells remained morphologically intact) (Table 2). In the group IV, the foam addition resulted in similar decrease in number of normal cells as it was observed in the group II. However, when the mixture was diluted with Lake's extender, the decrease in number of normal cells was the highest, in comparison with one observed during other steps of treatment. It decreased by further 17.4 percent points, and only $52.3 \%$ cells remained normal after these two stages of treatment in relation to the fresh semen (Table 2).

Further decrease in percent of live morphologically normal spermatozoa was observed in semen of groups III and IV after supplementation with 6\% DMA and 5 minutes equilibration at $4{ }^{\circ} \mathrm{C}$. The decrease however, was lower in the semen diluted without foam (group III) than in one supplemented previously with proctodeal gland foam. When comparing with the fresh semen, the number of live normal cells decreased by 20.7 and 28.3 percent points, respectively. A similar results, 
Table 2. Percentage of live normal spermatozoa in quail fresh semen, semen supplemented with Lake's extender or proctodeal gland foam and 6\% DMA ( $\mathrm{n}=11$; means \pm SD)

\begin{tabular}{|c|c|c|c|c|}
\hline \multirow[b]{2}{*}{ Semen samples } & \multicolumn{4}{|c|}{ Male groups } \\
\hline & $\begin{array}{c}\text { I - control } \\
\text { Fresh semen }\end{array}$ & $\begin{array}{c}\text { II } \\
\text { With foam }\end{array}$ & $\begin{array}{c}\text { III } \\
\text { Extender }+ \text { DMA }\end{array}$ & $\begin{array}{c}\text { IV } \\
\text { Foam }+ \text { extender } \\
+ \text { DMA }\end{array}$ \\
\hline Freshly collected & $\begin{array}{c}62.8^{\mathrm{A} * \pm 6.28} \\
(100 \%)^{* *}\end{array}$ & $\begin{array}{c}53.5^{\mathrm{B}} \pm 4.61 \\
(100 \%)\end{array}$ & $\begin{array}{c}53.2^{\mathrm{B}} \pm 6.84 \\
(100 \%)\end{array}$ & $\begin{array}{c}52.2^{\mathrm{B}} \pm 4.89 \\
(100 \%)\end{array}$ \\
\hline $\begin{array}{l}\text { With foam } \\
\text { addition }\end{array}$ & & $\begin{array}{c}47.5 \pm 8.69 \\
(88.8 \%)\end{array}$ & - & $\begin{array}{c}44.7 \pm 8.41 \\
(85.6 \%)\end{array}$ \\
\hline $\begin{array}{l}\text { Diluted with } \\
\text { Lake's extender }\end{array}$ & - & - & $\begin{array}{c}45.9^{\mathrm{A}} \pm 7.33 \\
(86.3 \%)\end{array}$ & $\begin{array}{c}27.3^{\mathrm{B}} \pm 12.88 \\
(52.3 \%)\end{array}$ \\
\hline $\begin{array}{l}\text { Supplemented } \\
\text { with DMA }\end{array}$ & - & - & $\begin{array}{c}32.5^{\mathrm{a}} \pm 9.16 \\
(61.1 \%)\end{array}$ & $\begin{array}{c}23.9^{\mathrm{b}} \pm 6.15 \\
\quad(45.8 \%)\end{array}$ \\
\hline After insemination & $\begin{array}{c}49.8^{\mathrm{A}} \pm 4.60 \\
(79.3 \%)\end{array}$ & $\begin{array}{c}48.0^{\mathrm{A}} \pm 6.03 \\
(89.7 \%)\end{array}$ & $\begin{array}{c}28.7^{\mathrm{B}} \pm 6.69 \\
(53.9 \%)\end{array}$ & $\begin{array}{c}15.9^{\mathrm{C}} \pm 4.93 \\
(30.5 \%)\end{array}$ \\
\hline
\end{tabular}

*Values in rows followed by different superscripts differ significantly (A, B-P $\leq 0.01$; a, $\mathrm{b}(\mathrm{P} \leq 0.05)$.

** Relative changes - percent of spermatozoa that remained after subsequent stages of treatment in relation to the fresh semen $(100 \%)$.

which proved that subsequent stages of preparation of rooster and turkey semen for freezing process cause an increase in sperm deformations, were obtained by Bakst and Sexton (1979). Also Tselutin et al. (1999) reported that 6\% DMA decreased significantly the number of live normal spermatozoa in rooster semen, while Blanco et al. (2000), when testing viability of spermatozoa of different bird species in a medium with 6-30\% DMA, found $6 \%$ to be the most effective.

During the last stage of the experiment (semen remained after insemination) the significant differences in number of live cells have been observed, depending on the semen treatment method (Table $2)$. The number of live spermatozoa in undiluted semen or semen supplemented with foam (group I and II) was similar, and when comparing with semen evaluated after collection, decreased by 13.0 $(49.8$ vs. $62.8 \%)$ and $5.5(48.0$ vs. $53.5 \%)$ percent points, respectively. In the group III and IV the number of normal cells remaining after insemination decreased by 24.5 (28.7 vs. 53.3\%) and 36.3 (15.9 vs. $52.2 \%)$ percent points respectively and was significantly lower $(\mathrm{P} \leq 0.01)$ in comparison with group I and II (Table 2).
The unfavourable effect of DMA addition on spermatozoa morphology observed in group IV was intensified by the presence of foam. In this group only $30.5 \%$ remained intact, in relation to freshly collected semen, while in the group III-53.9\% (Table 2).

Fertility rates obtained in the course of experiment only to some extent depended on the number of spermatozoa in the inseminated semen doses. The highest fertility (91.4\%) was stated in the group B (fresh semen supplemented with foam), despite the lower, when compared to the group A, number of cells introduced in the insemination dose (Table 3). This result did not differ from fertility stated for naturally mated group (93.0\%). The fertility in the group $\mathrm{C}$ and $\mathrm{D}$ was significantly lower ( $\mathrm{P} \leq 0.01)$ when compared to groups $\mathrm{A}, \mathrm{B}$ or E. The fertility rate decreased with the decrease in number of inseminated cells.

There are different opinions on the importance of foam produced by quails. Amano and Watanabe (1966), Kobayashi et al. (1972) and Ogawa et al. (1974) proved that in semen diluents quail spermatozoa tend to form clusters. Fujihara et al. (1989) suggested that clustered spermatozoa are 
Table 3. Fertility of quails inseminated with fresh semen, semen diluted with Lake's extender, proctodeal gland foam and $6 \%$ DMA or mated naturally (means $\pm \mathrm{SD}$ )

\begin{tabular}{lccccc}
\hline \hline \multicolumn{1}{c}{ Items } & $\begin{array}{c}\text { Group A } \\
\text { Fresh semen }\end{array}$ & $\begin{array}{c}\text { Group B } \\
\text { With foam }\end{array}$ & $\begin{array}{c}\text { Group C } \\
\text { Exten.+DMA }\end{array}$ & $\begin{array}{c}\text { Group D } \\
\text { Foam+Exten } \\
\text { +DMA }\end{array}$ & $\begin{array}{c}\text { Group E } \\
\text { Natural } \\
\text { mating }\end{array}$ \\
\hline $\begin{array}{l}\text { Number of inseminated } \\
\text { normal cells (millions) }\end{array}$ & $16.30^{\mathrm{A} *} \pm 2.27$ & $11.45^{\mathrm{B}} \pm 3.00$ & $7.44^{\mathrm{Ca}} \pm 1.69$ & $4.86^{\mathrm{Cb}} \pm 2.44$ & - \\
$\begin{array}{l}\text { Number of set eggs } \\
\text { Fertility (\%) }\end{array}$ & 90 & 88 & 85 & 86 & 88 \\
\hline
\end{tabular}

*Values within rows followed by different superscripts differ significantly (A, B-P $\leq 0.01 ; a, b(\mathrm{P} \leq 0.05)$.

released by contact with foam, which may have a favourable effect on fertility. Our experiments confirm this observation. In the group B the fertility rate was the highest despite significantly lower, in comparison with group $\mathrm{A}$, sperm concentration and number of live normal cells. Also Fujihara and Koga (1991) obtained higher fertility (55.86\%) when inseminating quails with semen mixed with foam (compared to $42.9 \%$ after insemination with semen alone). In our experiments only spermatozoa supplemented with foam kept a high fertilising potency. Fertility of $91.4 \%$ on average, obtained in our experiment was similar to results of natural mating, which seems to be quite satisfactory.

A different foam effect can be observed at different temperature. Cheng et al. (1989 b) reported that spermatozoa stored with foam in vitro at room temperature kept motility for 90 minutes, while without foam lost it within 10 minutes. Fujihara and Koga (1991) and Fujihara et al. (1989) described the unfavourable effect of foam at low temperatures $\left(0-3^{\circ} \mathrm{C}\right)$, the latter was also confirmed by the results of our experiment. The presence of foam had a positive effect only when semen was extended at $20^{\circ} \mathrm{C}$.

The obtained results encourage the authors to continue the experiments on proctodeal gland foam effect on quail spermatozoa suspended in different diluents and cryoprotective agents and subject to freezing-thawing regimes, however a special attention should be paid to cryoprotectant level, time and temperature of equilibration, as well as on extender-cryoprotectant interaction.

\section{References}

Adkins EK. Electrical recording of copulation in quail. Physiology and Behaviour, 13 : 475-477. 1974.
Adkins-Regan E. Foam produced by male coturnix quail : what is its function. Auk, 116, $1: 184-193.1999$.

Amano $\mathrm{T}$ and Watanabe $\mathrm{S}$. Studies on artificial insemination in Japanese quail. 1. On a method of semen collection and evaluation of semen. Journal of Agricultural Science, 12 : 59-62. 1966.

Bakst MR and Sexton TJ. Fertilizing capacity and ultrastructure of fowl and turkey spermatozoa before and after freezing. Journal of Reproduction and Fertility, $55: 1-7.1979$.

Baumgartner J. Prepelica japonska ako laboratorne zviera. Veterinarstvo, Serie C : 70-72. 1990 (in Slovakian).

Blanco JM, Gee G, Wildt DE and Donoghue AM. Species variation in osmotic, cryoprotectant, and cooling rate tolerance in poultry, eagle, and peregrine falcon spermatozoa. Biology of Reproduction, $63: 1164-$ 1171. 2000.

Bunaciu M, Bunaciu P and Cimpeanu I. The influence of mating designed on the reproductive performance in Japanese quail. Proceedings $9^{\text {th }}$ European Poultry Conference, Glasgow, Vol. 1, pp. 314-316. 1994.

Buxton JR and Orcutt Jr. FS. Enzymes and electrolytes in the semen of Japanese quail. Poultry Science, 54 : 15561566. 1975.

Chełmońska B, Jerysz A, Lukaszewicz E, Kowalczyk A and Ujma M. Effect of semen collection method on quantitative and qualitative quail semen characteristics - Part I. British Poultry Science, (In press). 2005.

Cheng KM, Hickman AR and Nichols CR. Role of proctodeal gland foam of male Japanese quail in natural copulations. Auk, 106 : 279-285. 1989 a.

Cheng KM, McIntyre RF and Hickman AR. Proctodeal gland foam enhances competitive fertilization in domestic Japanese quail. Auk, 106 : 286-291. 1989 b.

Donoghue AM and Wishart GJ. Storage of poultry semen. Animal Reproduction Science, 62 : 231-232. 2000.

Fujihara N. Accessory reproductive fluids and organs in male domestic birds. World's Poultry Science Journal, 48 : 39-53. 1992.

Fujihara N, Nishiyama $\mathrm{H}$ and Koga O. Physiological characteristics of quail (Coturnix coturnix japonica) spermatozoa. Proceedings of the IV $^{\text {th }}$ International Congress of Andrology, Florence, Italy, pp. 225-229. 1989.

Fujihara $\mathrm{N}$ and Koga O. Physiological function of the 
dorsal proctodeal gland foam of the male quail. Proceedings of the World Quail Conference, Tartu-Tallin, Estonia, pp. 78-83. 1991.

Kobayashi S, Okamoto S and Matsuo T. The influence of the foamy materials on the fertilizing capacity of semen in the Japanese quail, Coturnix coturnix japonica. Agricultural Bulletin of Sage University, 32 : 89-95. 1972.

Lake PE. Studies on the dilution and storage of fowl semen. Journal of Reproduction and Fertility, I : 30-35. 1960.

Lukaszewicz E. Effects of semen filtration and dilution rate on morphology and fertility of frozen gander spermatozoa. Theriogenology, 55 : 1819-1829. 2001.

Lukaszewicz E. Cryopreservation of Anser anser L. gander semen. Zeszyty Naukowe AR we Wrocławiu, 440, CXC : 1-111. 2002 (in Polish).

Mohan J, Moudgal RP, Narayan R, Singh J and Singh RV. Prediction of the fertility potential of male Japanese quail. Proceedings of XXI World's Poultry Congress, Montreal, Canada, pp. 20-24. 2000.

Ogawa K, Nakanishi Y, Tojo H and Imanishi M. Effect of frothy fluid from cloacal gland on fertility in the Japanese quail (Coturnix coturnix japonica). Bulletin of Faculty of Agriculture, Kagoshima University, 24 : 35-40. 1974.

Seiwert CM and Adkins-Regan E. The foam production system of the male Japanese quail : characterisation of structure and function. Brain, Behavior and Evolution, 52 (2) : 61-80. 1998.

Tarasewicz Z, Udała J, Szczerbińska D, Dańczak A and Romaniszyn K. Quality of semen and selected testimetric features in male Japanese quails. Animal Reproduction Review, 31 : 179-184. 1997.

Tselutin K, Seigneurin F and Blesbois E. Comparison of cryoprotectants and methods of cryopreservation of fowl spermatozoa. Poultry Science, 78 : 586-590. 1999.

Wentworth BC and Mellen WJ. Egg production and fertility following various methods of insemination in Japanese quail (Coturnix coturnix japonica). Journal of Reproduction and Fertility, 6 : 215-220. 1963. 